J. Lake Sci. (湖泊科学), 2021, 33(5): 1350-1363

DOI 10. 18307/2021. 0505

(C) 2021 by Journal of Lake Sciences

\title{
动态调水过程水文和理化因子共同驱动丹江口水库库湾浮游植物季 节变化
}

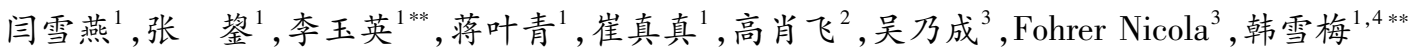
(1: 南阳师范学院水资源与环境工程学院, 河南省南水北调中线水源区流域生态安全国际联合实验室,南水北调中线水 源区水安全河南省协同创新中心, 南阳 473061)

(2:中国科学院城市环境研究所,城市环境与健康重点实验室,水生态健康研究组,厦门 361021)

(3:德国基尔大学水文与水资源管理系,基尔 24118)

(4:海南师范大学生命科学学院, 海口 571158)

摘 要: 丹江口水库是南水北调中线工程水源地, 库湾是水库型湖泊水质安全敏感区, 动态调水过程库湾水质直接关系 到调水安全. 为探究动态调水过程中丹江口水库库湾浮游植物季节变化规律和驱动因子, 2018 年 7 月 -2019 年 7 月, 从 丹库人库口到渠首调水口, 按季节对 18 个样点进行水质和浮游植物群落组成分析. 从整个丹库来看, 浮游植物全年总丰 度变化范围为 $0.43 \times 10^{3} \sim 4.7 \times 10^{6} \mathrm{cells} / \mathrm{L}$, 夏季最高, 秋季最低; Shannon-Wiener 指数春季最高, 秋季最低. 春季群落为硅 藻一绿藻型, 夏季为绿藻一硅藻型, 秋季为蓝藻型, 冬季为蓝藻一绿藻一硅藻型, 秋季蓝藻相对丰度最高. 位于丹库准保护 区内的库湾胡寨, 秋季水体电导率、总氮、总磷和叶绿素 $a$ 浓度最大, 蓝藻丰度最高. 从人库口经库湾到调水口, 浮游植物 群落组成存在明显演替. 从水文因子来看, 秋季水库水位较高, 调水流速和流量增加, 线性回归分析表明, 水位对 ShannonWiener 指数的影响最为明显, 水位越高则多样性指数越低; 流量和流速与 Shannon-Wiener 指数也呈负相关, 但相关性较 低. 方差分解分析发现, 水文因子和理化因子共同影响了浮游植物群落组成; 偏 Mantel 分析显示 3 个库湾浮游植物群落 组成与水温、氧化还原电位、化学需氧量、总氮和总磷浓度相关; 典范对应分析也表明, 总氮是影响库湾浮游植物群落组 成最显著的环境因子. 人类干扰活动改变了库湾水质理化性质, 强干扰提高了蓝藻门丰度. 因此, 控制库湾人类干扰强 度,尤其在水位和调水量较高的秋季,对于改善水体藻类组成、保护整个丹江口水库水质具有重要意义.

关键词: 丹江口水库;动态调水; 库湾; 浮游植物; 群落结构

\section{Hydrologic and physicochemical factors co-drive seasonal changes of phytoplankton during dynamic water diversion processes in the Danjiangkou Reservoir*}

Yan Xueyan ${ }^{1}$, Zhang Yun ${ }^{1}$, Li Yuying ${ }^{1 * *}$, Jiang Yeqing ${ }^{1}$, Cui Zhenzhen ${ }^{1}$, Gao Xiaofei ${ }^{2}$, Wu Naicheng ${ }^{3}$, Fohrer Nicola ${ }^{3} \&$ Han Xuemei ${ }^{1,4 * *}$

(1: International Joint Laboratory of Watershed Ecological Security and Collaborative Innovation Center of Water Security for Water Source Region of Middle Route Project of South-North Water Diversion in Henan Province, College of Water Resource and Environment Engineering, Nanyang Normal University, Nanyang 473061, P.R.China)

(2: Aquatic EcoHealth Group, Key Laboratory of Urban Environment and Health, Institute of Urban Environment, Chinese Academy of Sciences, Xiamen 361021, P.R.China)

(3: Department of Hydrology and Water Resources Management, University of Kiel, Kiel 24118, Germany)

(4: College of Life Sciences, Hainan Normal University, Haikou 571158, P.R. China)

Abstract: Reservoir bays are sensitive areas in terms of water quality and safety. This study analyzed water quality in the Dan-

* 2020-12-02 收稿;2021-01-01 收修改稿.

国家自然科学基金项目 (51879130, U1704124, 41601332)、河南省重点科技攻关项目 ( 2016151,17454 , 182102311021 ) 和河南省教育厅重点项目 (19B180007) 联合资助.

** 通信作者;E-mail: lyying200508@163.com; hanxuemei916@163.com. 
jiangkou Reservoir in China. Specifically, seasonal patterns and drivers of phytoplankton in the reservoir were explored during dynamic water diversion processes. Water quality and phytoplankton community samples were collected from 18 representative sites ranging from the inlet to the outlet of the reservoir, and samples were collected seasonally from July 2018 to July 2019. In the entire reservoir, the total abundance of phytoplankton ranged from $0.43 \times 10^{3}$ to $4.7 \times 10^{6}$ cells/ $\mathrm{L}$, with the highest abundance in summer and lowest in autumn. The Shannon-Wiener diversity index was the highest in spring and lowest in autumn. The phytoplankton community was composed of diatoms-Chlorophyta in spring, Chlorophyta-diatoms in summer, cyanobacteria in autumn, and cyanobacteria-Chlorophyta-diatoms in winter. The relative abundance of cyanobacteria was highest in autumn. Conductivity, total nitrogen (TN), total phosphorus (TP), and chlorophyll- $a$ were all highest in autumn, and cyanobacteria abundances were the highest in Huzhai Bay. An obvious succession of phytoplankton communities was observed from the inlet to the bay to the outlet. For hydrological factors, reservoir water levels were the highest in autumn, during which the regulating flow velocity and flow capacity increased. Linear regression analysis showed that water levels were negatively correlated with diversity indices. Variation partitioning showed that stochastic factors and physicochemical factors both influenced the formation of phytoplankton communities. The partial Mantel test indicated that the phytoplankton community composition in bays was correlated with the water temperature, oxidation-reduction potential, chemical oxygen demand, TN, and TP. Canonical correspondence analysis showed that TN was the most significant factor affecting the composition of phytoplankton communities in bays. These findings should be useful for future efforts to improve water quality in the Danjiangkou Reservoir.

Keywords: Danjiangkou Reservoir; dynamic water diversion; bay; phytoplankton; community composition

丹江口水库位于豫、鄂、陕交界的湖北省丹江口市和河南省浙川县境内, 是南水北调中线工程的水源 地, 保障其水质安全具有重要战略意义 ${ }^{[1]}$. 丹江口库区呈 “V”字型, 主要由汉江库区和丹江库区构成, 汉库 位于丹江口市, 形状狭长; 丹库位于淅川县, 面积较大, 较宽阔 ${ }^{[2]}$. 每年随着水库调度运转变化, 库区周边 150 160 m 高程形成大面积消落带. 丹库周边土地平坦, 以缓坡丘陵为主, 耕地占整个丹江口水库消落区耕 地面积的 $72.5 \%{ }^{\left[{ }^{[3]}\right.}$, 残留在耕地中的农药化肥等面源污染沉积物极易受到水体季节性侵蚀释放到水体中, 从而对库区水质造成严重威胁 ${ }^{[4]}$.

随丹江口水库扩容、水位抬升、蓄水量增大, 流域内地质和地表径流带来的外源性营养盐增加 ${ }^{[5]}$, 加之 水库运行管理 (调水及供水) 带来的水位波动、水力滞留时间、营养盐等水文条件和理化因子变化,均会增加 水库富营养化潜在风险 ${ }^{[6]}$. 以往研究多关注丹江口水库整个库体和部分支流的水质状况 ${ }^{[7-8]}$, 对库湾水质和 水生态的研究相对欠缺. 库湾是水库型湖泊水质安全的敏感区 ${ }^{[9]}$, 污染物易在此区域滞留和富集. 随着自然 和人为因素导致的污染物不断积累, 库湾发生富营养化的风险增高, 进而可能导致湖库整体水质恶化 ${ }^{[10]}$. 受季节变化和水库调度运行影响, 库湾的水位和水体交换能力等也会发生周期性变化. 因此, 研究动态调水 过程丹库库湾水质状况, 有利于监测丹江口水库水质, 预防水库水体富营养化, 保障水库水生态安全.

浮游植物是水生态系统的重要初级生产者, 群落结构和功能与水质密切相关 ${ }^{[1-12]}$, 其丰度和组成随营 养盐、温度、光照 ${ }^{[13]}$ 、水文条件 ${ }^{[14-15]}$ 等改变而变化, 常被用作水体健康状况指示生物 ${ }^{[16]}$. 有关湖泊的长期研 究表明, 浮游植物特定优势种组合常在固定时段重复出现, 这一过程常受水体物理、化学、水文和生物等因 子调控 ${ }^{[17-18]}$. 溶解氧、 $\mathrm{pH}$ 值、总磷 ( TP ) 和水温是丹江口水库浮游植物发生演替的关键因子 ${ }^{[19]}$, 而在镜泊湖 中, 水位波动、透光深度及 TP 与蓝藻生物量密切相关 ${ }^{[20]}$. 水位升高会促进蓝藻的生 长 $^{[21]}$, 人库流量减少和 温度升高可能是导致美国水库有害藻类异常增殖的原因 ${ }^{[22]}$. 尽管前人已经开展了许多浮游植物群落动态 变化及驱动因素的研究, 但丹江口水库作为主要水源地, 具有其个性特征, 如水位波动大、水体更新快等特 点 ${ }^{[23]}$. 因此, 了解丹库库湾浮游植物群落季节变化规律, 掌握引起浮游植物群落结构转变的环境因子, 实施 “一库一策”, 这对于动态调水过程丹江口水库监测和有效管理具有重要价值. 本研究重点探讨了南水北调 中线工程调水背景下丹库区域库湾浮游植物的群落特征, 尤其是浮游植物季节演替规律及其与水文和理化 因子的关系,为南水北调中线工程水源地丹江口水库的环境保护与科学管理提供重要理论支撑.

\section{1 材料与方法}

\section{1 样点概况}

丹江口水库位于北亚热带向温暖带的过渡带, 此区域年平均降水量 $743.5 \mathrm{~mm}$, 年内分配极不均匀, 每年 
7-9 月降水量较大. 2012 年丹江口大坝加高后, 常年蓄水位介于 $157 \sim 170 \mathrm{~m}$ 之间, 年调水量达 $130 \times 10^{8} \mathrm{~m}^{3}$, 有效调水量为 $95 \times 10^{8} \mathrm{~m}^{3}$, 水库扩容后库容增加至 $290.5 \times 10^{8} \mathrm{~m}^{3[24]}$. 丹库周边土地为缓坡丘陵, 土地利用方 式以耕地为主.

依据动态调水过程丹库水流方向, 从丹库主要供水支流丹江人库口黑鸡嘴 ( HJZ) 到南水北调中线干渠 陶岔调水口渠首 $(Q S)$, 共设置 18 个采样点 (图 1), 除黑鸡嘴和渠首两个样点外, 其余 16 个样点分别位于丹 库库心 $(\mathrm{KX})$ 和 3 个库湾. 3 个库湾均位于丹库东岸, 以往周边消落地以农田为主, 每个库湾设置 5 个样点. 自北向南, 依此为胡寨 (HZ1 HZ5) 、宋岗 (SG1 SG5) 和全店 (QD1 QD5). 其中, 胡寨位于水库准保护区范 围内, 在此区域有养鱼现象, 受人类活动干扰和面源污染影响较大, 平水期与库区隔离, 形成独立区域; 丰水 期与库区相通, 与丹库形成一个整体. 宋岗位于二级保护区内, 是重要客运码头, 人类活动干扰频繁. 全店位 于一级保护区域内,受人类活动干扰相对较少.

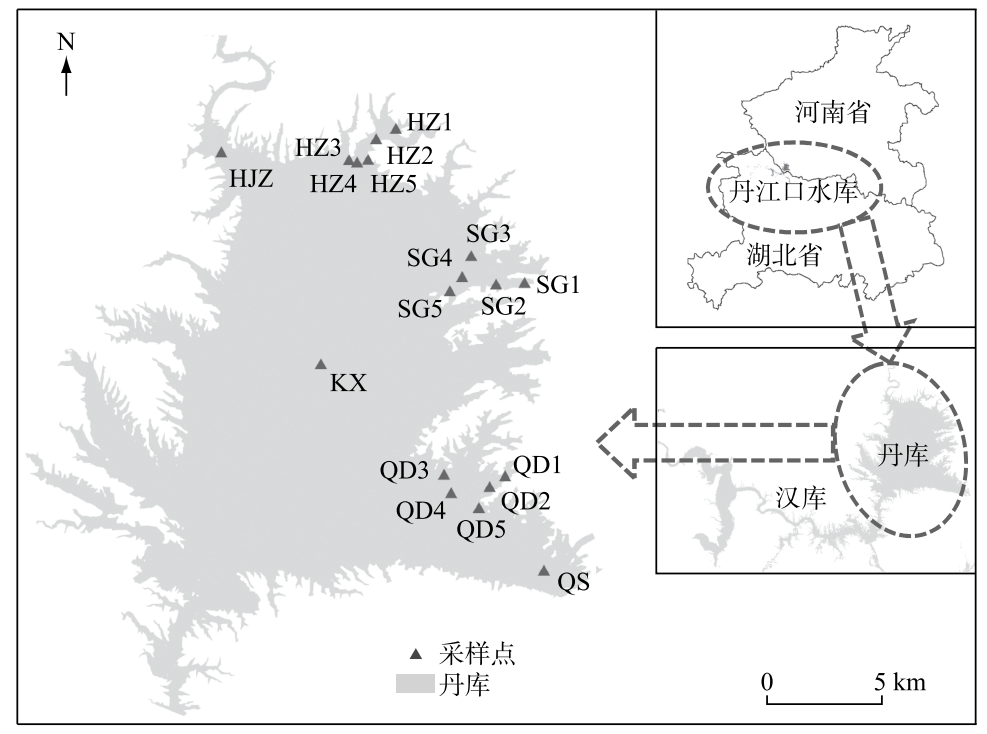

图 1 丹库样点分布

Fig.1 Distribution of the sampling sites in Danjiang Section, Danjiangkou Reservoir

\section{2 样品采集与测定}

分别于 2018 年 $7 、 10$ 月和 2019 年 $1 、 5 、 7$ 月进行 5 次水样和浮游植物样品的采集. 柱状采水器采集 $0 \sim$ $50 \mathrm{~cm}$ 表层水样 $2 \mathrm{~L}$, 装入聚乙烯采样瓶后, 低温避光保存, 用于水质测定. 柱状采水器另采集表层水 $2 \mathrm{~L}$, 加 人 $30 \mathrm{~mL}$ 鲁哥试剂固定, 室内经分液漏斗静置沉淀 $48 \mathrm{~h}$, 吸去上清液, 保留 $30 \sim 50 \mathrm{~mL}$ 浓缩样品, 定量分析浮 游植物群落组成.

水质理化指标 (包括水深) 测定参照《地表水环境质量标准》(GB 38382-2002) ${ }^{[25]}$, 使用多参数水质测 定仪 (YSI EXO) 现场测定水温、 $\mathrm{pH}$ 值、溶解氧 ( DO) 、氧化还原电位 ( ORP) 和电导率 (Cond), 使用 $\mathrm{SAN}^{++}$连 续流动分析仪测定总氮 $(\mathrm{TN})$ 、氨氮 $\left(\mathrm{NH}_{3}-\mathrm{N}\right)$ 、硝态氮 $\left(\mathrm{NO}_{3}^{-}-\mathrm{N}\right)$ 和总磷 $(\mathrm{TP})$ 浓度; 采用紫外分光光度法测定 高镇酸盐指数 $\left(\mathrm{COD}_{\mathrm{Mn}}\right)^{[26]}$; 采用重铬酸钾回流法测定化学需氧量 $(\mathrm{COD})$; 采用分光光度法测定叶绿素 $a$ (Chl. $a)^{\text {浓度 }}{ }^{[27]}$. 浮游植物鉴定参考文献 $[28-30]$.

\section{3 数据处理}

物种丰富度指数 $(S)$ 、Shannon-Wiener 多样性指数 $\left(H^{\prime}\right)$ 和 Mcnaughton 优势度指数 $(y)$ 用于表征藻类的 多样性特征: $S$ 为物种数; $H^{\prime}=-\sum P_{i} \ln P_{i}^{[31]} ; y=f_{i}\left(n_{i} / N\right)$, 当 $y>0.02$ 时, 定为优势种 ${ }^{[32]}$. 式中, $P_{i}=n_{i} / N, P_{i}$ 为 第 $i$ 个物种个体数量与所有个体总数量的比值, $n_{i}$ 为第 $i$ 个物种的个体总数, $N$ 为所有物种的数量, $f_{i}$ 为第 $i$ 种在各点位的出现频率. 
采用单因素或多因素 ANOVA 探讨季节或样点间环境因子和浮游植物群落的差异,采用 Pearson 相关性 分析浮游植物丰度、多样性指数和环境因子的相关关系, 相关统计分析在 IBM SPSS Statistics 23 软件中完成. 主成分分析 (principal component analysis, PCA) 用于分析基于环境因子的样点分布特征, 典范对应分析 (canonical correspondence analysis, CCA) 用于分析样点浮游植物群落分布与环境因子之间的相互关系 ${ }^{[33]}$, 邻体 矩阵主坐标分析 ( principal coordinates of neighbor matrices, PCNM) 用于分析样点间的空间关系. 变差分解、 PCA 和 CCA 分析主要基于 R3.6.3 软件 vegan 包完成,(偏) Mantel 相关分析基于 R3.6.3 软件 ggcor 包完成, 样点分布地图基于 ArcGIS 10.2 (ESRI, Redlands, CA, USA) 完成.

\section{2 结果}

\section{1 水文与理化因子分析}

2018 年 7 月 - 2019 年 7 月,丹江口水库全年平均水位 $156.64 \mathrm{~m}$,水位季节性波动明显, 9 月 (秋季) 水位 达到最高, 4 月 (春季) 水位最低 (图 2a). 调水口流速全年平均值为 $0.76 \mathrm{~m} / \mathrm{s}$, 流量平均值为 $203.48 \mathrm{~m}^{3} / \mathrm{h}$ (图 $2 b$ ). 流速与流量变化趋势基本一致, 秋季丰水期达到最高, 冬季平水期最低, 与丹江口水库水位变化并 不完全一致.
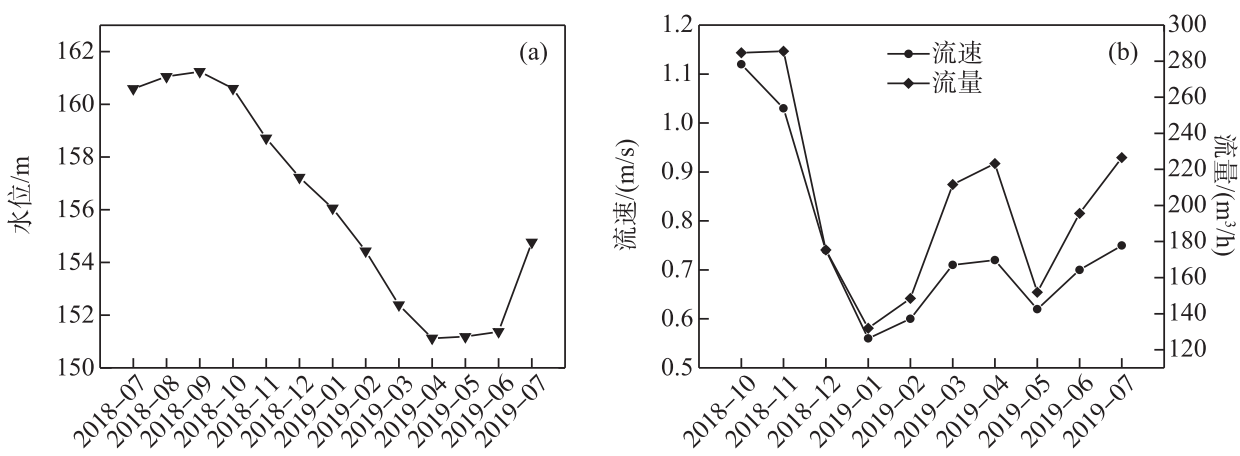

图 2 丹库水位与调水口流速和流量的变化

Fig.2 Changes of water level, water flow rate and velocity in Danjiang Section, Danjiangkou Reservoir

不同季节各样点主要环境因子经标准化处理后, 进行 PCA 排序分析(图 3). PCA 分析结果显示, PC1 轴解释度 为 $19.04 \%, P C 2$ 轴解释度为 $18.46 \%$, 不同季节样点有聚集 现象,但差异不明显; 不同类型样点间聚集现象不明显, 但 发现在夏季, 人库口黑鸡嘴、库心、调水口渠首与库湾样点 区分明显, 而库湾间差异较小; 秋季, 黑鸡嘴与库湾、库心和 渠首样点的理化因子间存在差异.

丹库采样点主要理化因子分析结果 (表 1 ) 显示, 人库 口黑鸡嘴的 $\mathrm{NH}_{3}-\mathrm{N} 、 \mathrm{NO}_{3}^{-}-\mathrm{N}$ 和 $\mathrm{COD}_{\mathrm{Mn}}$ 浓度显著高于其他样 点, 到达库心和调水口渠首时, $\mathrm{NH}_{3}-\mathrm{N}$ 和 $\mathrm{NO}_{3}^{-}-\mathrm{N}$ 浓度均有 所下降. 与其他样点相比, 3 个库湾 $\mathrm{NH}_{3}-\mathrm{N}$ 和 $\mathrm{NO}_{3}^{-}-\mathrm{N}$ 浓度 均较低. 结果也显示, 库湾胡寨 $\mathrm{ORP} 、$ Cond 、 TN 、TP 和 Chl. $a$ 浓度最高, 库湾宋岗 COD 浓度最高.

4 个季节水体理化因子变化情况见表 2 . 水温、ORP、 Cond 、TN 和 TP 浓度均呈现明显的季节变化规律, 秋季 ORP 最高,夏季 ORP 最低. Cond 与之相反,夏季最大, 秋季 最小. $\mathrm{TN}$ 浓度在秋季达到最高值, 其他 3 个季节水平一致.

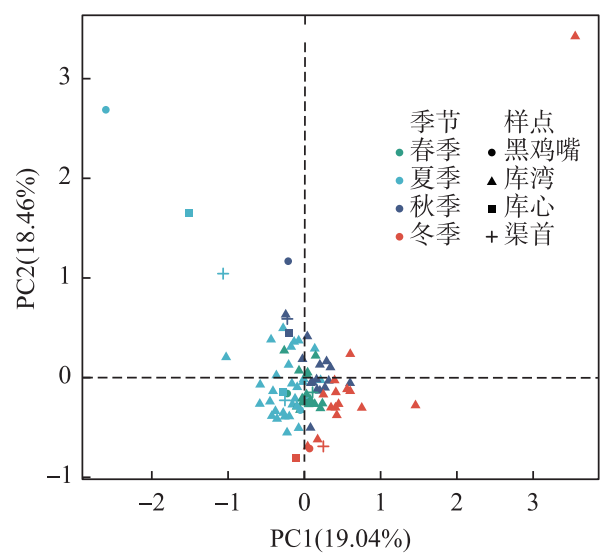

图 3 丹库不同季节样点环境因子 PCA 排序

Fig.3 PCA of environmental variables in different seasons in Danjiang Section, Danjiangkou Reservoir 
$\mathrm{TP}$ 浓度则是冬季最高,春、夏季最低,其他指标 4 个季节无显著差异.

表 1 丹库水体主要理化因子参数*

Tab.1 Parameters of the main physico-chemical factors of water quality in Danjiang Section, Danjiangkou Reservoir

\begin{tabular}{|c|c|c|c|c|c|c|}
\hline 指标 & 黑鸡嘴 & 库心 & 胡寨 & 宋岗 & 全店 & 渠首 \\
\hline $\mathrm{DO} /(\mathrm{mg} / \mathrm{L})$ & $8.65^{\mathrm{bc}}$ & $9.29^{c}$ & $7.76^{\mathrm{ab}}$ & $7.61^{\mathrm{b}}$ & $7.34^{\mathrm{a}}$ & $8.68^{\mathrm{bc}}$ \\
\hline $\mathrm{ORP} / \mathrm{mV}$ & $184.5^{\mathrm{a}}$ & $210.0^{\mathrm{b}}$ & $211.6^{\mathrm{b}}$ & $195.1^{\mathrm{ab}}$ & $192.2^{\mathrm{a}}$ & $204.6^{\mathrm{ab}}$ \\
\hline Cond $/(\mu \mathrm{S} / \mathrm{cm})$ & $245.46^{\mathrm{ab}}$ & $235.54^{\mathrm{a}}$ & $274.32^{\mathrm{b}}$ & $259.79^{\mathrm{ab}}$ & $256.44^{\mathrm{ab}}$ & $246.78^{\mathrm{ab}}$ \\
\hline $\mathrm{TN} /(\mathrm{mg} / \mathrm{L})$ & $1.57^{\mathrm{ab}}$ & $1.49^{\mathrm{ab}}$ & $2.26^{\mathrm{b}}$ & $1.51^{\mathrm{a}}$ & $1.49^{\mathrm{ab}}$ & $1.21^{\mathrm{a}}$ \\
\hline $\mathrm{NH}_{3}-\mathrm{N} /(\mathrm{mg} / \mathrm{L})$ & $0.086^{\mathrm{c}}$ & $0.061^{\mathrm{b}}$ & $0.026^{\mathrm{a}}$ & $0.022^{\mathrm{a}}$ & $0.024^{\mathrm{a}}$ & $0.050^{\mathrm{b}}$ \\
\hline $\mathrm{NO}_{3}^{-}-\mathrm{N} /(\mathrm{mg} / \mathrm{L})$ & $1.127^{\mathrm{c}}$ & $1.003^{\mathrm{b}}$ & $0.746^{\mathrm{a}}$ & $0.739^{\mathrm{a}}$ & $0.655^{\mathrm{a}}$ & $0.941^{\mathrm{b}}$ \\
\hline $\mathrm{TP} /(\mathrm{mg} / \mathrm{L})$ & $0.014^{\mathrm{ab}}$ & $0.011^{\mathrm{a}}$ & $0.036^{\mathrm{b}}$ & $0.017^{\mathrm{ab}}$ & $0.030^{\mathrm{ab}}$ & $0.010^{\mathrm{a}}$ \\
\hline $\mathrm{COD} /(\mathrm{mg} / \mathrm{L})$ & $11.90^{\mathrm{ab}}$ & $12.39^{\mathrm{ab}}$ & $12.42^{\mathrm{a}}$ & $12.42^{\mathrm{b}}$ & $12.41^{\mathrm{ab}}$ & $10.45^{\mathrm{a}}$ \\
\hline $\mathrm{COD}_{\mathrm{Mn}} /(\mathrm{mg} / \mathrm{L})$ & $2.90^{\mathrm{b}}$ & $2.35^{\mathrm{ab}}$ & $2.60^{\mathrm{ab}}$ & $2.37^{\mathrm{a}}$ & $2.45^{\mathrm{ab}}$ & $2.7^{\mathrm{b}}$ \\
\hline Chl. $a /(\mu \mathrm{g} / \mathrm{L})$ & $1.55^{\mathrm{a}}$ & $1.37^{\mathrm{a}}$ & $4.35^{\mathrm{b}}$ & $1.76^{\mathrm{a}}$ & $1.59^{\mathrm{a}}$ & $1.34^{\mathrm{a}}$ \\
\hline 水深/m & $31.10^{\mathrm{b}}$ & $28.36^{\mathrm{b}}$ & $10.48^{\mathrm{a}}$ & $12.66^{\mathrm{a}}$ & $12.94^{\mathrm{a}}$ & $14.71^{\mathrm{a}}$ \\
\hline
\end{tabular}

* 同一行不同小写字母表示样点在 $P<0.05$ 水平达到显著性差异,下同.

表 2 丹库不同季节水体理化因子

Tab.2 Physico-chemical factors of Danjiang Section, Danjiangkou Reservoir in different seasons

\begin{tabular}{|c|c|c|c|c|}
\hline 指标 & 春季 & 夏季 & 秋季 & 冬季 \\
\hline $\mathrm{WT} /{ }^{\circ} \mathrm{C}$ & $15.47^{\mathrm{b}}$ & $28.90^{\mathrm{d}}$ & $23.44^{\mathrm{c}}$ & $10.66^{\mathrm{a}}$ \\
\hline $\mathrm{pH}$ & 8.49 & 8.48 & 8.36 & 7.80 \\
\hline $\mathrm{DO} /(\mathrm{mg} / \mathrm{L})$ & 7.95 & 7.86 & 7.26 & 7.80 \\
\hline $\mathrm{ORP} / \mathrm{mV}$ & $202.00^{\mathrm{b}}$ & $157.34^{\mathrm{a}}$ & $248.72^{\mathrm{c}}$ & $181.39^{\mathrm{b}}$ \\
\hline Cond $/(\mu \mathrm{S} / \mathrm{cm})$ & $271.33^{b}$ & $277.76^{b}$ & $223.00^{\mathrm{a}}$ & $254.00^{\mathrm{b}}$ \\
\hline $\mathrm{TN} /(\mathrm{mg} / \mathrm{L})$ & $1.46^{\mathrm{a}}$ & $1.58^{\mathrm{a}}$ & $2.50^{\mathrm{b}}$ & $1.34^{\mathrm{a}}$ \\
\hline $\mathrm{NH}_{3}-\mathrm{N} /(\mathrm{mg} / \mathrm{L})$ & 0.03 & 0.05 & 0.03 & 0.02 \\
\hline $\mathrm{NO}_{3}^{-}-\mathrm{N} /(\mathrm{mg} / \mathrm{L})$ & $0.80^{\mathrm{ab}}$ & $0.81^{\mathrm{ab}}$ & $0.84^{\mathrm{b}}$ & $0.61^{\mathrm{a}}$ \\
\hline $\mathrm{TP} /(\mathrm{mg} / \mathrm{L})$ & $0.01^{\mathrm{a}}$ & $0.01^{\mathrm{a}}$ & $0.03^{\mathrm{ab}}$ & $0.04^{\mathrm{b}}$ \\
\hline $\mathrm{COD} /(\mathrm{mg} / \mathrm{L})$ & $11.59^{\mathrm{ab}}$ & $11.93^{\mathrm{ab}}$ & $12.68^{\mathrm{b}}$ & $9.96^{\mathrm{a}}$ \\
\hline $\mathrm{COD}_{\mathrm{Mn}} /(\mathrm{mg} / \mathrm{L})$ & 2.59 & 2.64 & 2.27 & 2.41 \\
\hline Chl. $a /(\mu \mathrm{g} / \mathrm{L})$ & 2.72 & 3.32 & 1.67 & 1.84 \\
\hline 水深/m & $11.09^{\mathrm{a}}$ & $12.37^{\mathrm{ab}}$ & $19.60^{\mathrm{b}}$ & $11.78^{\mathrm{ab}}$ \\
\hline
\end{tabular}

\section{2 浮游植物群落组成特征}

本研究共鉴定出浮游植物 7 门 68 属 92 种, 其中绿藻门种类最多 (35 种), 占浮游植物总种类数的 $38.04 \%$; 其次为硅藻门(29 种), 占 $31.52 \%$; 蓝藻门 13 种, 占 $15.29 \%$; 隐藻门和裸藻门均为 5 种, 分别占 $5.90 \%$; 甲藻门 4 种, 占 $4.70 \%$; 金藻门仅发现 1 种. 浮游植物总丰度全年变化范围为 $0.43 \times 10^{3} \sim 4.7 \times 10^{6}$ cells $/ \mathrm{L}$, 平均丰度为 $1.94 \times 10^{5}$ cells $/ \mathrm{L}$. 浮游植物季节差异性明显 (图 4), 春季硅藻和绿藻为主要优势门, 夏季 大部分样点绿藻代替硅藻成为第一优势门, 蓝藻在各库湾所占比例上升; 秋季蓝藻成为库湾的绝对优势类 群, 而其他 3 个样点依然是绿藻为第一优势门; 进人冬季后, 硅藻比例上升, 浮游植物组成又呈现多样化特 征,但渠首蓝藻比例依然较高.

18 个样点共笁选出 34 个浮游植物优势物种 $(y>0.02)$. 春季, 16 个优势物种主要隶属于硅藻门和绿藻 门, 其中硅藻门小环藻 (Cyclotella sp.) 的优势度最高 (0.281), 黑鸡嘴与库心的优势类群相似, 库湾全店和胡 寨与渠首的优势类群相似, 库湾宋岗的优势类群与其他样点差异较大. 夏季, 21 个优势物种主要属于硅藻 门、绿藻门和蓝藻门, 其中硅藻门颗粒直链藻极狭变种 (Melosira granulata var. angustissima) 的优势度最大 

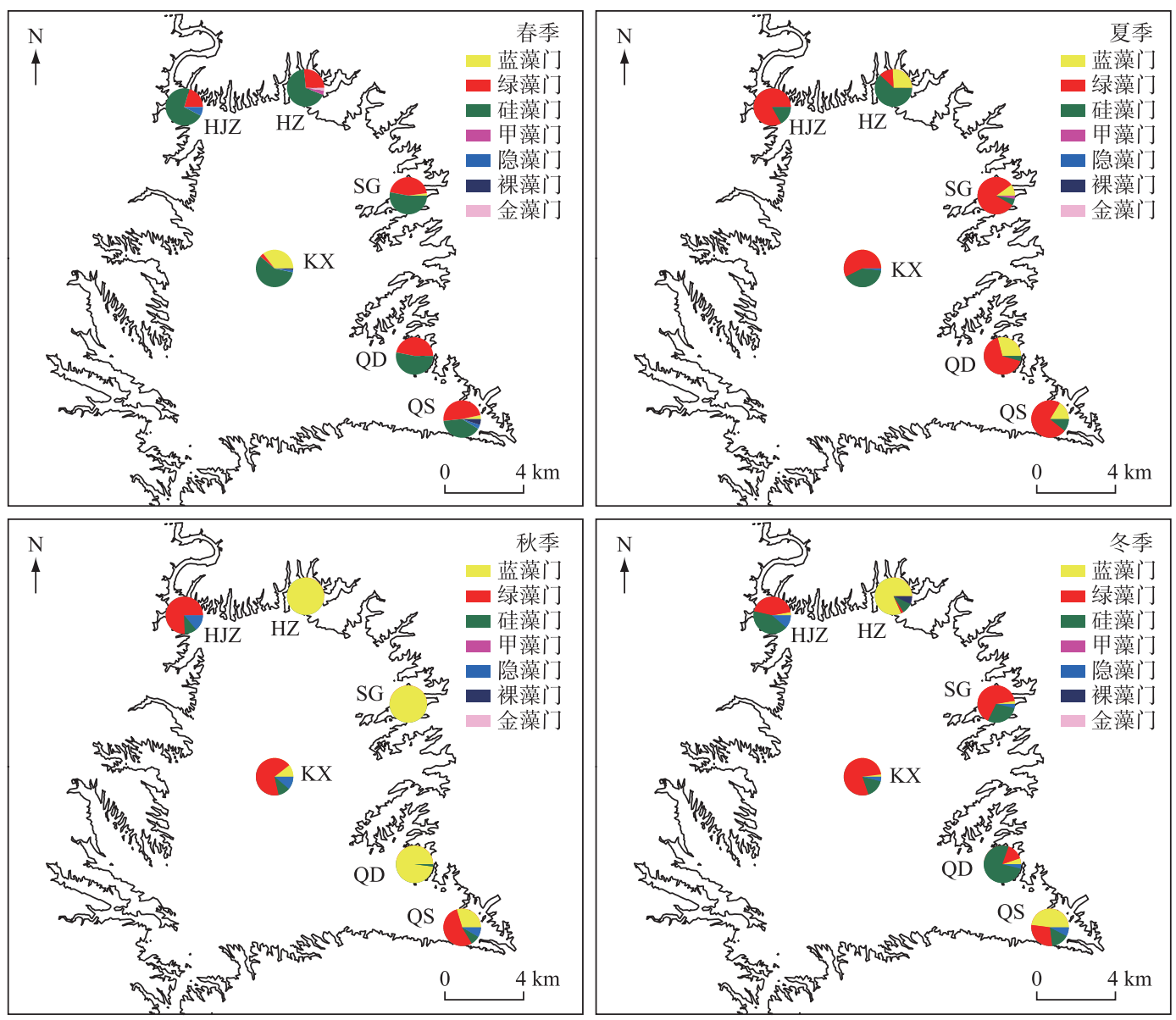

图 4 丹库不同季节各样点浮游植物相对丰度

( $\mathrm{HJZ}$ : 黑鸡嘴; $\mathrm{HZ}$ :胡寨; $\mathrm{SG}$ : 宋岗; QD :全店; $\mathrm{KX}$ :库心; QS :渠首)

Fig.4 Phytoplankton relative abundance in different seasons in Danjiang Section, Danjiangkou Reservoir

(0.384), 黑鸡嘴与库心的优势类群相似,库湾胡寨、宋岗和全店的优势类群相似,渠首的优势类群与其他样 点差异较大. 秋季, 12 个优势物种主要属于硅藻门和蓝藻门, 依然是硅藻门的颗粒直链藻极狭变种优势度最 大 $(0.289)$, 黑鸡嘴、库心、宋岗和全店的优势类群相似, 胡寨和渠首与这 4 个样点差异显著. 冬季, 13 个优势 物种主要属于硅藻门, 硅藻门的颗粒直链藻 (Melosira granulata $)$ 优势度最大 $(0.236)$, 全店、宋岗和黑鸡嘴 优势类群相似,渠首、库心和胡寨与其有较大差异.

浮游植物多样性指数双因素方差分析表明, 总丰 度、物种数和 Shannon-Wiener 指数在季节、地点和两者 交互作用上均存在极显著差异 (表 $3, P<0.01$ ). 物种数 变化范围为 $8 \sim 16$, Shannon-Wiener 指数为 $1.064 \sim$ 1.698. Tukey 多重比较表明, 总丰度夏季最高, 秋季最 低;物种数夏季最大, 秋冬季最小; Shannon-Wiener 指 数春季最高, 秋季最低, 从春季到秋季持续降低, 冬季 有所上升(表 4). 春季, 库心与黑鸡嘴 Shannon-Wiener

表 3 丹库多样性指数主体间效应检验结果

Tab.3 Test results of inter-subject effects of diversity indices of Danjiang Section, Danjiangkou Reservoir

\begin{tabular}{ccccc}
\hline 指数 & 检验值 & 季节 & 地点 & 季节×地点 \\
\hline 总丰度 & $F$ & 17.43 & 11.67 & 7.32 \\
& $P$ & $<0.001$ & $<0.001$ & $<0.001$ \\
$S$ & $F$ & 24.97 & 3.52 & 4.72 \\
& $P$ & $<0.001$ & 0.004 & $<0.001$ \\
$H^{\prime}$ & $F$ & 5.79 & 8.18 & 7.46 \\
& $P$ & 0.001 & $<0.001$ & $<0.001$ \\
\hline
\end{tabular}


表 4 不同季节丹库不同样点间浮游植物 Shannon-Wiener 指数的差异

Tab.4 Difference of Shannon-Wiener indices of phytoplankton among different sampling sites of Danjiang

Section, Danjiangkou Reservoir in different seasons

\begin{tabular}{ccccc}
\hline 样点 & 春季 & 夏季 & 秋季 & 冬季 \\
\hline 黑鸡嘴 & $0.771^{\mathrm{a}}$ & $2.003^{\mathrm{b}}$ & $1.128^{\mathrm{ab}}$ & $1.394^{\mathrm{a}}$ \\
胡寨 & $2.256^{\mathrm{c}}$ & $0.903^{\mathrm{a}}$ & $0.871^{\mathrm{a}}$ & $1.264^{\mathrm{a}}$ \\
宋岗 & $1.516^{\mathrm{b}}$ & $1.657^{\mathrm{ab}}$ & $0.962^{\mathrm{ab}}$ & $1.116^{\mathrm{a}}$ \\
全店 & $2.035^{\mathrm{bc}}$ & $1.740^{\mathrm{b}}$ & $1.199^{\mathrm{ab}}$ & $1.629^{\mathrm{a}}$ \\
库心 & $0.688^{\mathrm{a}}$ & $1.574^{\mathrm{ab}}$ & $1.818^{\mathrm{b}}$ & $1.183^{\mathrm{a}}$ \\
渠首 & $1.972^{\mathrm{bc}}$ & $2.070^{\mathrm{b}}$ & $1.223^{\mathrm{ab}}$ & $2.817^{\mathrm{c}}$ \\
\hline
\end{tabular}

指数相似, 其他样点 Shannon-Wiener 指数均升高; 夏 季, 与人库口黑鸡嘴相比, 仅库湾胡寨 ShannonWiener 指数降低; 但秋季, 这种差异不明显; 冬季, 与 其他样点相比, 渠首 Shannon-Wiener 指数升至最高.

\section{3 水文因子对浮游植物群落结构的影响}

为了进一步了解调水过程水文因子对浮游植物 群落组成的影响, 将优势门丰度和优势物种丰度与 丹江口水库水位和调水口渠首流速和流量进行 Pearson 相关性分析 (图 5). 蓝藻门丰度与流速、流 量呈极显著正相关, 其中蓝藻门的优势种鱼腥藻、微 囊藻、水华束丝藻丰度均与水位、流速和流量呈极显 著正相关. 硅藻门丰度与水位和流速呈极显著负相 关, 与流量呈显著负相关, 硅藻门的针杆藻 (Synedra sp.) 、菱形藻 (Nitzschia sp.) 、肘状针杆藻 (Synedra ulna) 和小环藻丰度均与水位呈显著负相关, 梅尼小环藻 (Cyclotella meneghiniana) 丰度与流量呈显著负相关. 绿藻门丰度与这 3 项水文因子无显著相关性, 但绿藻门 的空球藻丰度与水位呈显著负相关. 将浮游植物 Shannon-Wiener 指数与水位、流速和流量进行线性回归分 析表明, Shannon-Wiener 指数与水位、流速和流量呈极显著负相关 (图 6), 但 $R^{2}$ 值均较小, 水位对 ShannonWiener 指数的影响最为明显, 流量影响最小.

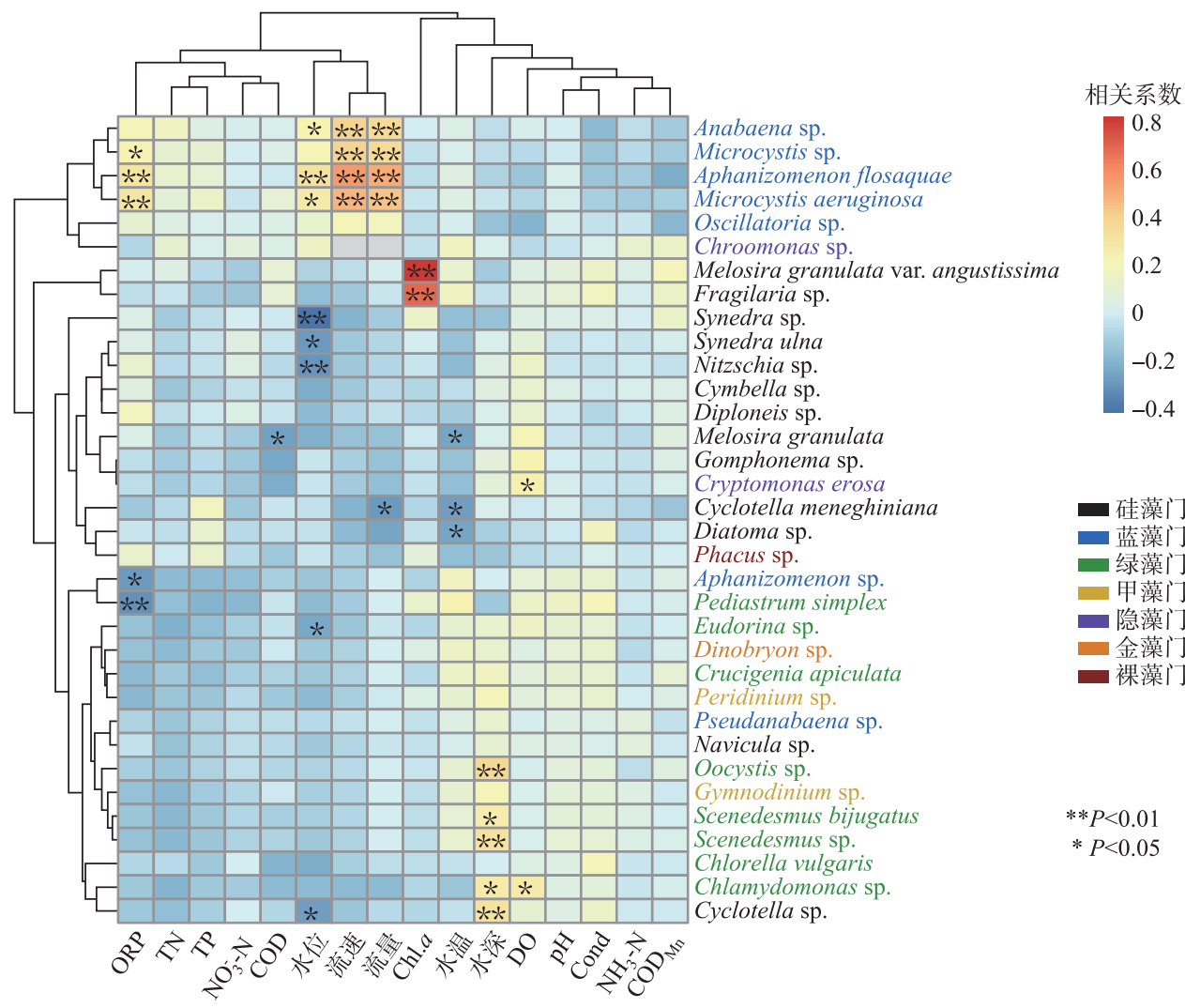

图 5 丹库浮游植物优势物种丰度与环境因子的相关性热图

Fig.5 Heatmap of correlation between abundance of phytoplankton dominant species and environmental parameters in Danjiang Section, Danjiangkou Reservoir 

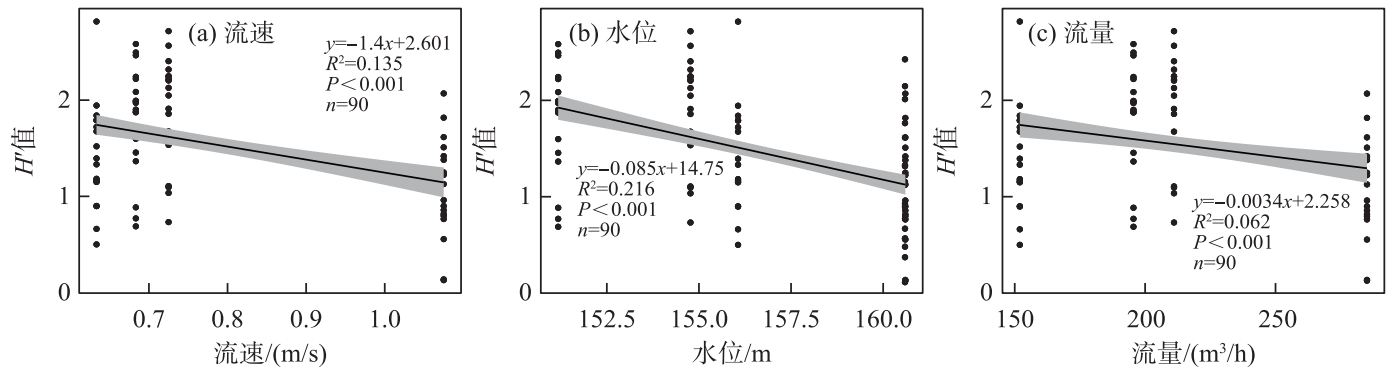

图 6 丹库浮游植物 Shannon-Wiener 指数与水文因子的线性回归分析

Fig.6 Linear regression of Shannon-Wiener indices of phytoplankton and hydrological factors in Danjiang Section, Danjiangkou Reservoir

\section{4 理化因子对浮游植物群落结构的影响}

为掌握不同类型环境因素对丹库浮游植物群落组成 的影响, 对季节、地点、理化因子 (含水深) 和 PCNM 进行方 差分解 (图 7). 这 4 类生态因子共解释了浮游植物群落组 成变化的 $39.0 \%$, 其中理化因子的解释率最高, 达到 $23 \%$; 其次为季节因子, 解释率为 $17 \%$; 地点差异的解释率为 $12 \%$; PCNM 解释率最低, 仅为 $9 \%$. 季节与理化因子共同解 释率为 $9.0 \%$. 地点、理化因子和 PCNM 三者共同解释率为 $6.0 \%$, 说明样点空间格局导致理化因子差异, 进而影响到 浮游植物群落分布.

利用偏 Mantel 相关性, 通过控制协变量, 分析了对丹 库浮游植物群落组成具有显著影响的理化因子 (表 5 ). 结 果表明, 影响浮游植物群落的显著因子样点间具有明显的 不同. 在丹库人库口黑鸡嘴, 并未发现影响浮游植物群落

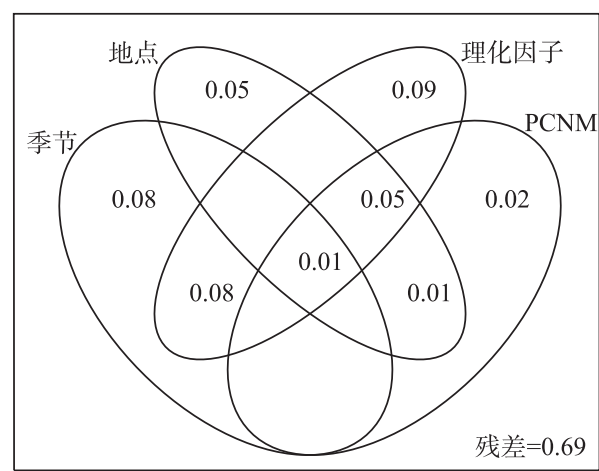

图 7 丹库浮游植物群落结构方差分解 Fig.7 Variation partitioning of phytoplankton community structure in Danjiang Section, Danjiangkou Reservoir

表 5 丹库不同样点浮游植物群落与理化因子的偏 Mantel 系数 ${ }^{1)}$

Tab.5 Partial Mantel coefficients of phytoplankton community and physico-chemical factors at different sampling sites in Danjiang Section, Danjiangkou Reservoir

\begin{tabular}{|c|c|c|c|c|c|c|}
\hline 指标 & 黑鸡嘴 & 胡寨 & 宋岗 & 全店 & 库心 & 渠首 \\
\hline WT & -0.305 & $0.394^{* *}$ & $0.403^{* *}$ & $0.459^{\text {*** }}$ & -0.083 & 0.288 \\
\hline $\mathrm{pH}$ & -0.263 & $0.291^{* *}$ & $0.312^{* *}$ & 0.096 & -0.329 & 0.056 \\
\hline DO & -0.321 & $0.161 *$ & 0.078 & 0.112 & 0.147 & 0.188 \\
\hline ORP & -0.172 & $0.263^{* *}$ & $0.273^{* *}$ & $0.206^{*}$ & 0.300 & -0.189 \\
\hline Cond & -0.135 & 0.079 & 0.380 ** & 0.131 & 0.290 & -0.145 \\
\hline $\mathrm{TN}$ & 0.126 & 0.020 & $0.253^{*}$ & 0.092 & 0.588 & 0.607 \\
\hline $\mathrm{NH}_{3}-\mathrm{N}$ & 0.198 & -0.028 & -0.038 & -0.047 & 0.417 & 0.184 \\
\hline $\mathrm{NO}_{3}^{-}-\mathrm{N}$ & 0.126 & 0.189* & -0.056 & $0.126 *$ & $0.513 *$ & 0.660 \\
\hline $\mathrm{TP}$ & 0.353 & 0.055 & 0.297 ** & $0.157^{*}$ & -0.407 & -0.230 \\
\hline COD & -0.031 & $0.122 *$ & $0.153^{*}$ & $0.152 *$ & 0.092 & -0.095 \\
\hline $\mathrm{COD}_{\mathrm{Mn}}$ & 0.818 & 0.101 & -0.010 & -0.091 & -0.420 & 0.053 \\
\hline Chl. $a$ & 0.080 & 0.075 & 0.053 & 0.030 & -0.377 & -0.062 \\
\hline 水深 & 0.050 & 0.063 & $0.185^{*}$ & 0.119 * & -0.271 & -0.030 \\
\hline
\end{tabular}

1) 加粗字体表明显著性因子; $*$ 表示 $P<0.05$, ** 表示 $P<0.01$. 
的显著因子. 3 个库湾浮游植物群落组成均与水温、ORP 和 $\mathrm{COD}$ 浓度有关, 除此以外, 胡寨浮游植物群落形 成还受到 $\mathrm{pH} 、 \mathrm{DO}$ 浓度和 $\mathrm{NO}_{3}^{-}-\mathrm{N}$ 浓度的影响; 宋岗浮游植物群落形成受到 $\mathrm{pH} 、$ Cond 、 $\mathrm{TN}$ 浓度、TP 浓度和水 深的影响; 全店浮游植物群落则受到 $\mathrm{NO}_{3}^{-}-\mathrm{N}$ 浓度、 $\mathrm{TP}$ 浓度和水深的影响. 库心仅发现 $\mathrm{NO}_{3}^{-}-\mathrm{N}$ 浓度对浮游植 物群落有较大影响,渠首未发现显著的影响因子.

为进一步明确影响浮游植物群落分布的环境因子, 将浮游植物物种与环境因子进行 CCA 分析 (图 8a). 结果表明, DO、 $\mathrm{NO}_{3}^{-}-\mathrm{N} 、 \mathrm{TN} 、 \mathrm{Chl} . a$ 、水温、Cond 和样点水深与群落分布有显著性相关 $(P<0.05), \mathrm{CCA} 1$ 轴的解 释量为 $11.73 \%, \mathrm{CCA} 2$ 轴的解释量为 $7.87 \%$. 其中, $\mathrm{NO}_{3}^{-}-\mathrm{N} 、 \mathrm{TN} 、 \mathrm{Chl} . a$ 浓度和水温与库湾群落分布关系最为密 切, $\mathrm{TN}$ 沿第 1 轴上分布最长, 是影响浮游植物群落结构最主要的环境因子; 而在库心, 浮游植物群落组成受 Cond 和水深的影响较大. 各样点 $\mathrm{TN}$ 浓度与各样点在 CCA1 轴的得分进行线性回归后发现, TN 浓度与不同 样点群落组成具有极显著相关性 $\left(R^{2}=0.102, P<0.001\right)$ (图 8b).
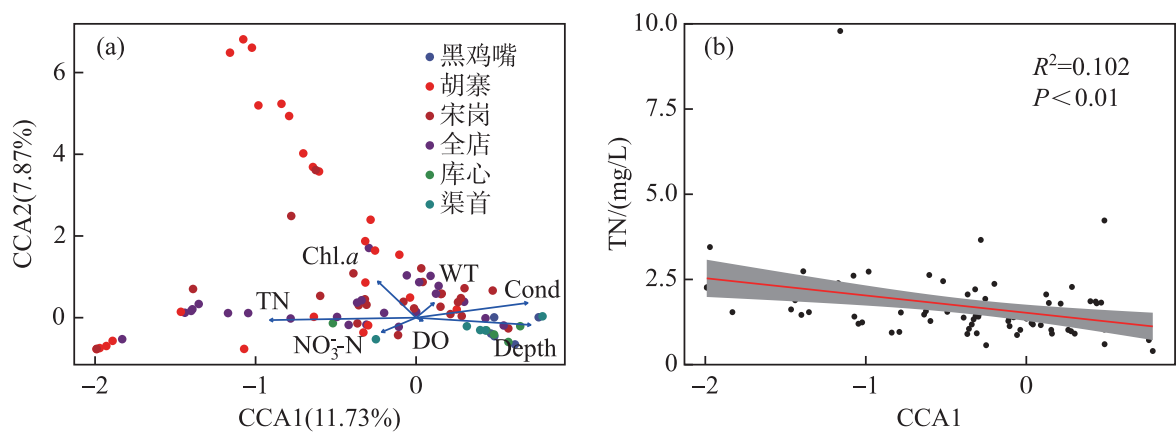

图 8 丹库浮游植物群落与理化因子的 CCA 排序

Fig.8 CCA of phytoplankton communities and physico-chemical factors in Danjiang Section, Danjiangkou Reservoir

浮游植物不同物种丰度与理化因子进行 Mantel 相关性分析后发现 (图 9), 蓝藻门丰度与水温、 $\mathrm{pH}$ 、 Cond 、COD 有显著相关性; 绿藻门丰度与水温、pH、DO 浓度、ORP、Cond 、TN 浓度、TP 浓度和水深呈显著性相 关; 硅藻门丰度仅与水温、 $\mathrm{NH}_{3}-\mathrm{N}$ 浓度、 $\mathrm{NO}_{3}^{-}-\mathrm{N}$ 浓度和水深相关, 其他门与水温、 $\mathrm{pH}$ 和 $\mathrm{TP}$ 浓度呈显著相关.

将浮游植物优势物种丰度与理化因子进行 Pearson 相关性分析 (图 5) 发现, 蓝藻门的水华束丝藻 (Aphanizomenon flosaquae) 和微囊藻 (Microcystis sp.) 丰度与 ORP 呈显著正相关, 束丝藻 (Aphanizomenon sp.) 丰度与 ORP 呈显著负相关. 硅藻门的颗粒直链藻极狭变种丰度 $(r=0.82)$ 和脆杆藻 (Fragilaria sp.) 丰度 $(r=0.70)$ 均 与 Chl. $a$ 浓度呈极显著正相关, 颗粒直链藻丰度与 COD 和水温呈显著负相关, 梅尼小环藻和等片藻 (Diatoma sp.) 丰度均与水温呈显著负相关, 小环藻丰度与水深呈极显著正相关. 绿藻门的单角盘星藻 (Pediastrum simplex) 丰度与 ORP 呈极显著负相关, 卵囊藻 (Oocystis sp.) 和栅藻丰度均与水深呈极显著正相关, 双 对栅藻 (Scenedesmus bijugatus) 和衣藻 (Chlamydomonas sp.) 丰度均与水深呈显著正相关, 衣藻丰度还与 DO 浓度呈显著正相关. 隐藻门的虽蚀隐藻 (Cryptomonas erosa) 丰度与 DO 浓度呈显著正相关.

\section{3 讨论}

\section{1 丹库浮游植物季节变化特征}

丹江口水库丹库浮游植物群落季节差异明显. 春季硅藻和绿藻为优势类群, 水温是影响藻类群落组成 的重要因素 ${ }^{[34]}$, 在横山水库 ${ }^{[35]}$ 、香溪河水库 ${ }^{[36]}$ 及大溪水库 ${ }^{[37]}$ 等水体中均发现水温能够影响浮游植物群落 结构. 适宜温度可以提高藻类的光合作用, 加快细胞新陈代谢, 促进其生长繁殖 ${ }^{[38]}$. 硅藻门丰度与水温呈正 相关, 春季有利于硅藻丰度增加. 但硅藻门的优势物种颗粒直链藻、梅尼小环藻、等片藻丰度却与水温呈显著 负相关, 说明适宜的温度 $\left(10 \sim 25^{\circ} \mathrm{C}\right)$ 有利于硅藻生长, 但温度的过分升高反而会抑制硅藻的丰度. 因此, 研 究发现, 进人夏季后硅藻门的优势地位丧失. 丹江口水库春季水位最低, 硅藻门的针杆藻、菱形藻、肘状针杆 藻和小环藻丰度均与水位呈显著负相关, 说明低水位的扰动有利于硅藻门某些藻类的生长繁殖. 夏季水温 


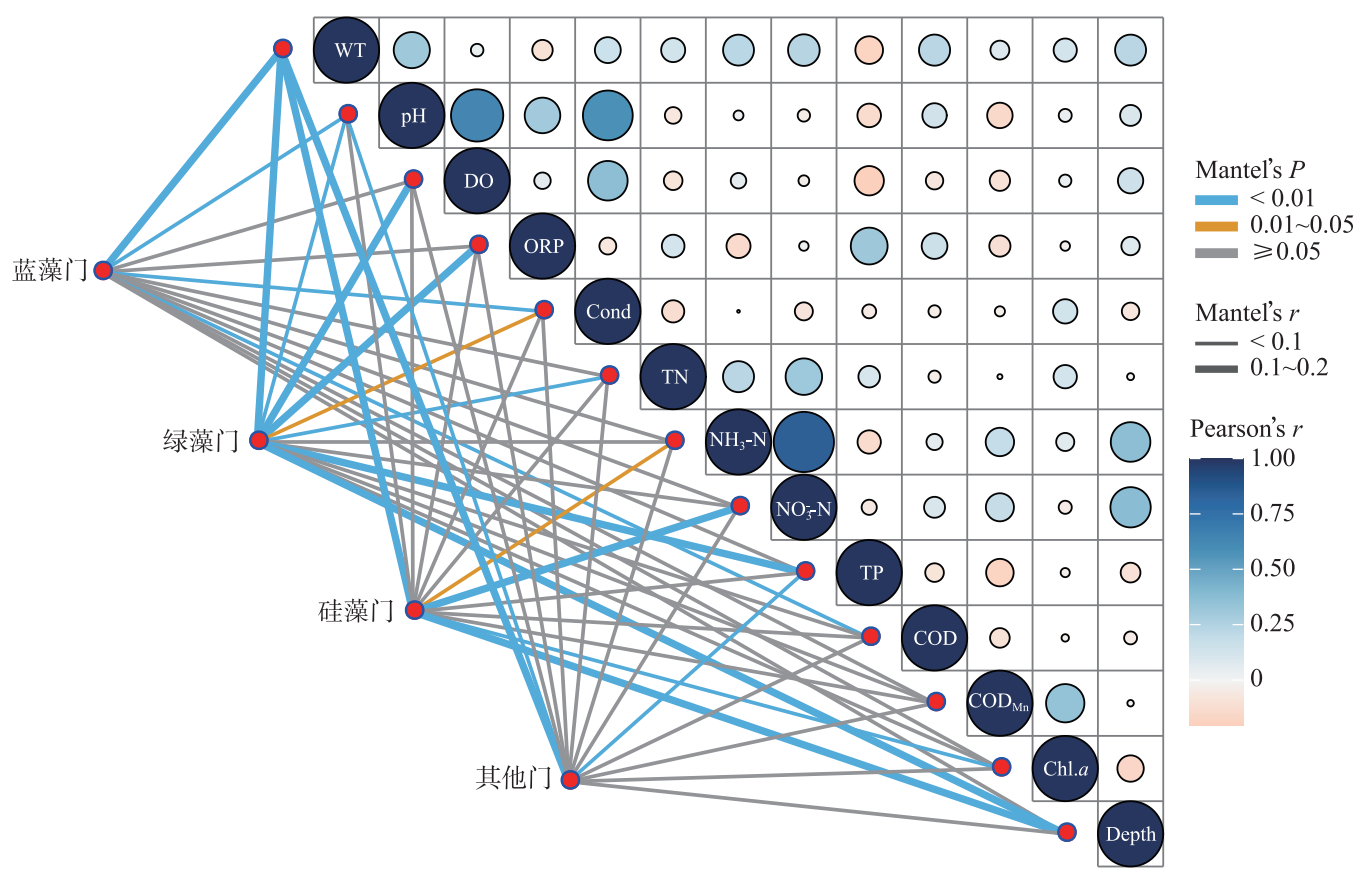

图 9 丹库理化因子与浮游植物群落不同门物种丰度的相关分析

Fig.9 Physico-chemical variables and abundance of phytoplankton phyla composition in Danjiang Section, Danjiangkou Reservoir

升高, 光照增强, 绿藻依然为优势类群, 但硅藻优势地位下降, 蓝藻比例上升. 较高温度能促进藻类的生长繁 殖,并使蓝藻成为优势类群 ${ }^{[39]}$, 蓝藻优势形成是其自身生理特征以及营养盐、温度、光照、水文和气象条件等 诸多因素综合作用的结果 ${ }^{[40]}$. 进人秋季, 优势类群为蓝藻, 这是因为这个时期丹江口水库进人丰水期, 伴随 降雨量的增加, 进人库内的面源污染物增加, 为蓝藻繁殖提供了丰富的营养盐. 从水质结果也可以看出, 秋 季水体中 ORP、TN、TP 和 COD 浓度均高于其他季节. 也有研究指出, 营养化水平较低水体以硅藻型浮游植 物群落为主, 而营养化水平较高水体以蓝一绿藻型群落为主 ${ }^{[41]}$, 蓝藻门的大量繁殖与 TP 浓度等营养物密切 相关 ${ }^{[42]}$. 冬季, 随着水位的下降, 进人水体中的营养盐和有机物数量降低, 蓝藻和绿藻比例下降, 硅藻比例 上升,蓝藻、绿藻和硅藻成为这个季节的共同优势物种.

与其他学者的研究结果对比发现, 调水前后丹江口水库浮游植物群落组成的季节变化差异明显. 申恒 伦等 ${ }^{[11]}$ 指出 2007- 2008 年春季丹江口水库浮游植物以硅藻一蓝藻型为主, 夏、秋季演替为隐藻一蓝藻型, 冬 季发展为硅藻一隐藻一甲藻型, 春季和秋季硅藻所占比例最大; 谭香等 ${ }^{[7]}$ 在 $2009-2010$ 年的调查发现, 春、 秋和冬季硅藻在数量上均占绝对优势, 夏季蓝藻为优势门. 王英华等 ${ }^{[19]}$ 发现, 2014- 2015 年春季和冬季硅 藻均为丹江口水库优势类群, 但夏季绿藻占优势. 本研究结果与王英华等的研究结果更为相像, 笔者推测, 这可能是因为 2012 年丹江口大坝水库扩容, 影响了丹江口水库的物质交流和能量转化, 从而改变了浮游植 物群落季节动态. 水文调控导致的湖泊高水位运行和水动力减弱, 会使湖泊沿岸带生境逐渐丧失, 湖泊内有 机碳和营养盐滞留效应增强, 促进了浮游生物的生长 ${ }^{[43]}$. 冯宇墨等也发现好汉泊水库扩容后, 浮游植物丰 度和生物量均有所增加, 其中绿藻门和蓝藻门上升最为明显 ${ }^{[44]}$.

\section{2 调水影响丹库浮游植物群落组成}

在秋季高水位期, 调水口具有较高的流速和流量, 浮游植物群落多样性较低, Shannon-Wiener 指数与水 位、调水口流速和流量呈显著负相关, 其中与水位的关系更为密切. 由此可以看出, 水文因子波动引起的强 扰动会抑制某些浮游植物的生长 ${ }^{[45]}$. 李哲等发现, 流量与降雨作为主要的物理扰动因子, 引起澎溪河浮游 
植物多样性变化. 蓄水期水位上升、流量骤降, 水体扰动强度加剧导致藻类多样性下降 ${ }^{[46]}$, 这与笔者的研究 结果相一致. 张毅敏等也发现, 流速和风力等因子扰动较强时, 会降低藻类丰度 ${ }^{[47]}$. 因此, 秋季调水口较低 的浮游植物多样性与该季节较高调水量带来的强扰动有关. 水动力作为水生态系统中的主要驱动力, 会直 接或间接地引起其他环境条件的改变, 从而影响浮游植物的生长繁殖, 进而影响更高级营养级, 甚至整个生 态系统 ${ }^{[48]}$.

\section{3 丹库库湾浮游植物群落特征}

库湾浮游植物群落结构与人库口黑鸡嘴、库心和调水口渠首区分明显. 调水口浮游植物群落组成受人 库口和库湾群落的共同影响, 库湾水体富营养化程度直接影响到调水的质量. 库湾是水库中受人类活动干 扰最强烈的区域, 水质产生明显变化, 进而影响到浮游植物的群落结构 ${ }^{[49]}$, 夏季和秋季这种效应最为明显. 夏季宋岗和全店两个库湾的浮游植物均为绿藻一蓝藻型, 进入秋季后, 3 个库湾的浮游植物几乎完全由蓝藻 构成, 而黑鸡嘴、库心和渠首 3 个样点则由绿藻和蓝藻共同构成. 研究指出, 随着水体富营养化的发展, 水体 中浮游植物群落逐渐从以硅藻和绿藻为主演替为以蓝藻为主 ${ }^{[50-54]}$, 蓝藻门的微囊藻、鱼腥藻、颤藻和束丝藻 为优势种 ${ }^{[55-56]}$, 这些藻类也是本次研究发现的优势类群. 蓝藻是水体富营养化引起水华的主要藻类, 浅水湖 泊和水产养殖池塘的水体易暴发蓝藻 ${ }^{[57]}$. 库湾受人类扰动强烈, 在夏季和秋季有发生水体富营养化的风险. 而且笔者也发现, 夏、秋季浮游植物物种多样性指数均下降, 物种多样性的降低意味着生态系统结构的简单 化,进而影响到生态系统的生产力和稳定性.

库湾内部样点间浮游植物群落结构存在差异. 尽管夏季库湾胡寨蓝藻相对丰度较低, 但从绝对丰度来 看, 夏、秋季, 胡寨蓝藻丰度远远高于其他两个库湾, 藻类总丰度也最高. 胡寨位置受人类活动干扰较多 (附 近有渔业养殖), 养殖活动增加了水体中有机物和营养盐的浓度, 提高了蓝藻的丰度. 研究结果也显示, 与其 他两个库湾相比, 胡寨水体 Cond TN、TP 和 Chl. $a$ 浓度最高, 这与笔者的推测相一致. 同时, 胡寨周边主要为 农田丘陵, 夏、秋季降雨频繁, 降雨量大, 多种污染负荷物随雨水流人河道和湖泊, 导致较多有机污染物和营 养盐排人库湾,造成胡寨夏、秋季浮游植物丰度最高.

\section{4 结论}

丹江口水库丹库浮游植物群落组成以硅藻、绿藻、蓝藻和隐藻为主, 春、冬季物种多样性高, 群落结构复 杂, 夏、秋季绿藻和蓝藻比例高. 动态调水过程, 秋季库区高水位、调水口高流速和高流量的扰动, 会引起浮 游植物多样性下降. 水文因子和理化因子共同影响了浮游植物群落组成动态变化, 水温和营养盐仍然是决 定浮游植物群落结构的主控因素, 同时水位和流速也是影响丹江口水库浮游植物群落结构的主要驱动因子. 人类干扰强度变化会改变库湾水质理化性质, 强干扰有利于提高蓝藻门的相对丰度, 增加丹江口水库发生 富营养化的风险. 本文关于水质、藻类和水文的复杂关系研究为丹江口水库的保护和管理提供了理论支持.

\section{5 参考文献}

[ 1 ] Straškraba M, Tundisi JG, Duncan A eds. State-of-the-art of reservoir limnology and water quality management. Comparative reservoir limnology and water quality management. Dordrecht: Springer Netherlands, 1993: 213-288. DOI: 10.1007/ 978-94-017-1096-1_13.

[ 2 ] Wu HJ, Peng JH, Han DJ et al. Composition and ecological changes of phytoplankton in Danjiangkou Reservoir. J Lake $S c i, 1996,8(1)$ : 43-50. DOI : 10.18307/1996.0106. [鸟红娟, 彭建华, 韩德举等. 丹江口水库浮游植物及其演变. 湖泊科学, 1996, 8(1): 43-50.]

[ 3 ] Han YP, Pan LD, Chen Y et al. Analysis on spatial distribution and influencing factors of nitrogen in sediments of waterfluctuating zone in Danjiangkou reservoir area. Journal of North China University of Water Resources and Electric Power: Natural Science Edition, 2019, 40(6) : 75-80. DOI: 10.19760/j.ncwu.zk.2019084. [ 韩宇平, 潘礼德, 陈莹等. 丹江口 库区消落带淹水期沉积物氮素空间分布及影响因素分析. 华北水利水电大学学报: 自然科学版, 2019, 40(6): 75-80.]

[ 4 ] Ye S, Tan DB, Zhang Y. Investigation and analysis on the characteristics of land-use status of Danjiangkou water level fluctuating zone. Journal of Yangtze River Scientific Research Institute, 2016, 33(11): 17-20. [叶松, 谭德宝, 张显. 丹 江口水库消落带土地利用现状调查及特点分析. 长江科学院院报, 2016, 33(11): 17-20.] 
[ 5 ] Jiang YJ, He W, Liu WX et al. The seasonal and spatial variations of phytoplankton community and their correlation with environmental factors in a large eutrophic Chinese lake (Lake Chaohu). Ecological Indicators, 2014, 40: 58-67. DOI: 10. 1016/j.ecolind.2014.01.006.

[ 6 ] Hoyer AB, Moreno-Ostos E, Vidal J et al. The influence of external perturbations on the functional composition of phytoplankton in a Mediterranean reservoir. Hydrobiologia , 2009, 636(1) : 49-64. DOI: 10.1007/s10750-009-9934-2.

[ 7 ] Tan X, Xia XL, Cheng XL et al. Temporal and spatial pattern of phytoplankton community and its biodiversity indices in the Danjiangkou Reservoir. Environmental Science, 2011, 32(10) : 2875-2882. DOI: 10.13227/j.hjkx.2011.10.008. [谭 香, 夏小玲, 程晓莉等. 丹江口水库浮游植物群落时空动态及其多样性指数. 环境科学, 2011, 32(10): 2875-2882. ]

[ 8 ] Zhang AJ, Yao WF, Wu ZJ. Study on variation characteristics of inflow runoff to Danjiangkou Reservoir. Yangtze River, $2020,51(3): 81-86,93$. [张爱静, 姚文锋, 吴智健. 丹江口水库人库径流变化特征分析. 人民长江, 2020,51 (3) : 81-86, 93.]

[ 9 ] Huang YP ed. Taihu Lake water environment and pollution control. Beijing: Science Press, 2002. [ 黄渏平. 太湖水环境 及其污染控制. 北京: 科学出版社, 2002.]

[10] Jia HY, Xu JF, Lei JS. Relationship of community structure of phytoplankton and environmental factors in Danjiangkou Reservoir Bay. Yangtze River, 2019, 50(5) : 52-58. [贾海燕, 徐建锋, 雷俊山. 丹江口库湾浮游植物群落与环境因 子关系研究. 人民长江, $2019, \mathbf{5 0}(5): 52-58$.]

[11] Shen HL, Xu YY, Wang L et al. Spatial and temporal variations of phytoplankton in Danjiangkou Reservoir and its affecting factors. Journal of Wuhan Botanical Research, 2011, 29(6) : 683-690. DOI: 10.3724/SP.J.1142.2011.60683. [申恒 伦, 徐耀阳, 王岗等. 丹江口水库浮游植物时空动态及影响因素. 植物科学学报, 2011, 29(6) : 683-690.]

[12] Zhou GJ, Kuang QJ, Hu ZY et al. Study on the succession of algae and the trend of water-blooms occurred in Xiangxi bay. Acta Hydrobiologica Sinica, 2006, 30 (1) : 42-46. [周广杰, 况琪军, 胡征宇等. 香溪河库湾浮游藻类种类演替及水 华发生趋势分析. 水生生物学报, 2006, 30(1) : 42-46.]

[13] Fang T, Li DJ, Yu LH et al. Effect of irradiance and phosphate on growth of nanophytoplankton and picophytoplankton. Acta Ecologica Sinica, 2006, 26(9): 2783-2790. [方涛, 李道季, 余立华等. 光照和营养盐磷对微型及微微型浮游 植物生长的影响. 生态学报, 2006, 26(9) : 2783-2790.]

[14] Bonilla S, Conde D, Aubriot L et al. Influence of hydrology on phytoplankton species composition and life strategies in a subtropical coastal lagoon periodically connected with the Atlantic Ocean. Estuaries, 2005, 28(6) : 884-895.

[15] Yin W, Shi ZH, Lei A. Research on water environment of Danjiangkou Reservoir. Yangtze River, 2011, 42 (13) : 90-94. [尹炜，史志华，雷阿林. 丹江口水库水环境问题分析研究. 人民长江，2011，42(13) : 90-94.]

[16] Padisák J, Borics G, Grigorszky I et al. Use of phytoplankton assemblages for monitoring ecological status of lakes within the water framework directive: The assemblage index. Hydrobiologia, 2006, 553(1) : 1-14. DOI: 10.1007/s10750-0051393-9.

[17] Reynolds CS ed. Ecology of phytoplankton. Cambridge: Cambridge University Press, 2006.

[18] Karadžić V, Subakov-Simić G, Krizmanić J et al. Phytoplankton and eutrophication development in the water supply reservoirs Garaši and Bukulja (Serbia). Desalination, 2010, 255(1/2/3) : 91-96. DOI: 10.1016/j.desal.2010.01.009.

[19] Wang YH, Chen L, Niu Y et al. Spatio-temporal variation in phytoplankton community and its influencing factors in DanJiangkou Reservoir. J Lake Sci, 2016, 28(5) : 1057-1065. DOI: 10.18307/2016.0516. [王英华, 陈雷, 牛远等. 丹江 口水库浮游植物时空变化特征. 湖泊科学, 2016, 28(5): 1057-1065.]

[20] Wang X, Liu LS, Li L et al. Correlation analysis of algae composition and environmental factors in Jingpo Lake. China Environmental Science, 2015, 35(11) : 3403-3413. [汪星, 刘录三, 李黎等. 镜泊湖浮游藻类组成及其与环境因子的 相关分析. 中国环境科学, 2015, 35(11): 3403-3413.]

[21] Lin QQ, Hu R, Han BP. Effect of hydrodynamics on nutrient and phytoplankton distribution in Liuxihe Reservoir. Acta Ecologica Sinica, 2003, 23(11): 2278-2284. [林秋奇, 胡㓞, 韩博平. 流溪河水库水动力学对营养盐和浮游植物 分布的影响. 生态学报, 2003, 23(11): 2278-2284.]

[22] Beaver JR, Kirsch JE, Tausz CE et al. Long-term trends in seasonal plankton dynamics in Lake Mead ( Nevada-Arizona, USA) and implications for climate change. Hydrobiologia, 2018, 822 (1) : 85-109. DOI: 10.1007/s10750-018-3638-4.

[23] Zhang J, Min YW, Duan WX. Key techniques research and practice for dynamic control of water level in Danjiangkou Reservoir during flood season. Technology and Economy of Changjiang, 2019, 3(2): 81-90. [张俊, 闵要武, 段唯金金. 丹江 口水库汛期水位动态控制关键技术研究与实践. 长江技术经济, 2019, 3(2)：81-90.] 
[24] Fu XP. The situation of water resources in China and the Middle Route of South-to-North Water Diversion Project. Henan Water Resources \& South-to-North Water Diversion, 2008: 1-2. [傅新平. 我国水资源状况与南水北调中线工程. 河南 水利与南水北调, 2008: 1-2.]

[25] Editorial Board of “Monitoring and analysis methods of water and wastewater”, Ministry of Environmental Protection of the People's Republic of China ed. Monitoring and analysis methods of water and wastewater: fourth edition. Beijing: China Environmental Science Press, 2002. [ 国家环境保护总局《水和废水监测分析方法》编委会. 水和废水监测分析方 法: 第 4 版. 北京: 中国环境科学出版社, 2002.]

[26] Song BJ, Meng XL, Zhang YL et al. UV spectrophotometric method for the determination of permanganate index of water. China Metrology, 2009, (10): 82-83. [宋保军, 孟新立, 张艳丽等. 紫外分光光度法测定水中高锰酸盐指数. 中国 计量, 2009, (10): 82-83.]

[27] Sun W, Xia CY, Xu MY et al. Application of modified water quality indices as indicators to assess the spatial and temporal trends of water quality in the Dongjiang River. Ecological Indicators, 2016, 66: 306-312. DOI : 10.1016/j.ecolind.2016. 01.054 .

[28] Hu HJ, Wei YX eds. The freshwater algae of China: Systematics, taxonomy and ecology. Beijing: Science Press, 2006. [胡鸿均, 魏印心. 中国淡水藻类一一系统, 分类及生态. 北京: 科学出版社, 2006.]

[29] Zhang Q, Liu GX, Hu ZY. Study on freshwater genus Peridiniopsis (Dinophyta) from China. Acta Hydrobiologica Sinica, 2012, 36(4) : 751-764. DOI : 10.3724/SP.J.1035.2012.00751. [张琪, 刘国祥, 胡征宇. 中国淡水拟多甲藻属研究. 水生生物学报, 2012, 36(4): 751-764.]

[30] Zhu HZ, Chen JY eds. Bacillariophyta of the Xizang Plateau. Beijing: Science Press, 2000. [ 朱惠忠, 陈嘉佑. 中国西藏 硅藻. 北京: 科学出版社, 2000.]

[31] Wang XY, Sun MJ, Wang JM et al. Microcystis genotype succession and related environmental factors in Lake Taihu during cyanobacterial blooms. Microbial Ecology, 2012, 64(4) : 986-999. DOI: 10.1007/s00248-012-0083-1.

[32] Xing BW, Xu JX, Cao Y et al. Phytoplankton community structure and ecological evaluation in summer, Lake Changhai of Jiuzhaigou National Nature Reserve. J Lake Sci, 2020, 32(4) : 1088-1099. DOI: 10.18307/2020.0417. [邢冰伟, 徐季 雄, 曹玥等. 九寨沟国家级自然保护区长海夏季浮游植物群落结构及生态评价. 湖泊科学, 2020, 32(4): 1088-1099.]

[33] Ter Braak CJ, Smilauer P. CANOCO reference manual and CanoDraw for Windows user's guide: software for canonical community ordination( Version4.5). Ithaca: Microcomputer Power, 2002.

[34] Sheng HY, Yu ZM, Han YC et al. Phytoplankton community and its relationship with environmental factors of a large riverine reservoir, Fuchunjiang Reservoir in subtropical China. J Lake Sci, 2010, 22(2) :235-243. DOI: 10.18307/2010. 0213. [ 盛海燕, 虞左明, 韩轶才等. 亚热带大型河流型水库一一富春江水库浮游植物群落及其与环境因子的关 系. 湖泊科学, 2010, 22(2):235-243.]

[35] Yang LJ, Yu PF, Zhu JQ et al. Community structure characteristics of phytoplankton and related affecting factors in HengShan Reservoir, Zhejiang, China. Chinese Journal of Applied Ecology, 2014, 25(2) : 569-576. DOI: 10.13287/j.10019332.2014.0060. [杨亮杰, 余鹏飞, 竺俊全等. 浙江横山水库浮游植物群落结构特征及其影响因子. 应用生态学 报, 2014, 25(2): 569-576.]

[36] Zhang QW, Song LX, Ji DB et al. Relationship between water quality of Xiangxi River Reservoir and the algal blooms in non-return area in the Three Gorges Reservoir Area. China Environmental Science, 2019, 39(7) : 3018-3026. [张庆文, 宋林旭, 纪道斌等. 香溪河库湾水质特征与非回水区水华响应关系. 中国环境科学, 2019, 39(7): 3018-3026.]

[37] Wang Q, Huang W, Chen KN et al. Phytoplankton community structure and trophic status evaluation in Reservior Daxi. Acta Scientiae Circumstantiae, 2020, 40(4) : 1286-1297. DOI: 10.13671/j.hjkxxb.2019.0497. [汪琪, 黄蔚, 陈开宁 等. 大溪水库浮游植物群落结构特征及营养状态评价. 环境科学学报, 2020, 40(4): 1286-1297.]

[38 ] Yan GH, Yin XY, Wang X et al. Effects of environmental factors on the composition of phytoplankton community in Sankou of the Yangtze River and the Western Dongting Lake. China Environmental Science, 2019, 39(6) : 2532-2540. [严广 寒, 殷雪妍, 汪星等. 长江三口-西洞庭湖环境因子对浮游植物群落组成的影响. 中国环境科学, 2019, 39(6): 2532-2540.]

[39] Zhu GW, Shi K, Li W et al. Seasonal forecast method of cyanobacterial bloom intensity in eutrophic Lake Taihu, China. J Lake Sci, 2020, 32(5): 1421-1431. DOI: 10.18307/2020.0504. [ 朱广伟, 施坤, 李未等. 太湖蓝藻水华的年度情势 预测方法探讨. 湖泊科学, 2020, 32(5) : 1421-1431.]

[40] Xu H, Chen J, Zhu GW et al. Effect of concentrations of phosphorus and nitrogen on the dominance of cyanobacteria. $J$ 
Lake Sci , 2019, 31(5) : 1239-1247. DOI: 10.18307/2019.0518. [许海, 陈洁, 朱广伟等. 水体氮、磷营养盐水平对 蓝藻优势形成的影响. 湖泊科学, 2019, 31(5): 1239-1247.]

[41] Carey CC, Ibelings BW, Hoffmann EP et al. Eco-physiological adaptations that favour freshwater cyanobacteria in a changing climate. Water Research, 2012, 46 (5) : 1394-1407. DOI: 10.1016/j.watres.2011.12.016.

[42] Xu H, Qin BQ, Zhu GW. Nutrient limitation of cyanobacterial growth in different regions of Lake Taihu in summer. China Environmental Science, 2012, 32(12) : 2230-2236. [许海, 秦伯强, 朱广伟. 太湖不同湖区夏季蓝藻生长的营养盐 限制研究. 中国环境科学, 2012, 32(12): 2230-2236.]

[43] Wang JY. Spatio-temporal patterns of hydrological regulation and ecological responses of lakes in northwest Yunnan [Dissertation]. Kunming: Yunnan Normal University, 2019. [王教元. 滇西北湖泊水文调控与生态环境响应的时空特征 [学位论文]. 昆明: 云南师范大学, 2019.]

[44] Feng YM, Ma CX, Yu HX. Changes in phytoplankton community and water quality after expansion of Haohanpo Reservoir. Chinese Journal of Fisheries, 2013, 26(5):41-46. [冯宇墨, 马成学, 于洪贤. 好汉泊水库扩容前后浮游植物群落及 水质的变化. 水产学杂志, 2013, 26(5):41-46.]

[45] Qian KM, Liu BG, Chen YW. Long term dynamics of phytoplankton functional groups in Lake Poyang during 2009-2016. $J$ Lake Sci, 2019, 31(4) : 1035-1044. DOI: 10.18307/2019.0402. [钱奎梅, 刘宝贵, 陈宇炜. 鄱阳湖浮游植物功能 群的长期变化特征(2009-2016 年). 湖泊科学, 2019, 31(4) : 1035-1044.]

[46] Li Z, Wang S, Guo JS et al. Phytoplankton diversity in backwater area of the Pengxi River in the Three Gorges Reservoir before and after $156 \mathrm{~m}$ impoundment. J Lake Sci, 2012, 24(2) : 227-231. DOI: 10.18307/2012.0209. [李哲, 王胜, 郭 劲松等. 三峡水库 $156 \mathrm{~m}$ 蓄水前后澎溪河回水区 藻类多样性变化特征. 湖泊科学, 2012, 24(2): 227-231.]

[47] Zhang YM, Zhang YC, Zhang LJ et al. The influence of lake hydrodynamics on blue algal growth. China Environmental Science, 2007, 27 (5): 707-711. [张毅敏, 张永春, 张龙江等. 湖泊水动力对蓝藻生长的影响. 中国环境科学, $2007,27(5): 707-711$.

[48] Shi SH. Responses of river phytoplankton community to heterogeneous hydrological environment induced by damming-A case study of Three Gorges reservoir [Dissertation]. Chongqing: Southwest University,2018. [史邵华. 河流浮游植物群 落对筑坝引发的异质性水文环境的响应——三三峡水库为例 [ 学位论文]. 重庆: 西南大学, 2018.]

[49] Sun CC, Wang YS, Sun S et al. Analysis dynamics of phytoplankton community characteristics in Daya Bay. Acta Ecologica Sinica, 2006, 26(12) : 3948-3958. [孙翠慈, 王友绍, 孙松等. 大亚湾浮游植物群落特征. 生态学报, 2006, 26 (12) : 3948-3958.

[50] Yang W, Zhu JY, Zhang KX et al. Community dynamics of phytoplankton and related affecting factors in a eutrophicated small pond. Environmental Science, 2015, 36(4) : 1309-1316. DOI: 10.13227/j.hjkx.2015.04.023. [ 杨文, 朱津永, 张 克金等. 一小型藻华池塘浮游植物群落动态及其影响因子研究. 环境科学, 2015, 36(4) : 1309-1316.]

[51] Nishikawa T, Tarutani K, Yamamoto T. Nitrate and phosphate uptake kinetics of the harmful diatom Eucampia zodiacus Ehrenberg, a causative organism in the bleaching of aquacultured Porphyra thalli. Harmful Algae, 2009, 8(3) : 513-517. DOI: $10.1016 /$ j.hal.2008.10.006.

[52] Chen YW, Fan CX, Teubner K et al. Changes of nutrients and phytoplankton chlorophyll-a in a large shallow lake, Taihu, China: An 8-year investigation. Hydrobiologia, 2003, 506/507/508/509(1/2/3) : 273-279. DOI: 10.1023/B: HYDR. 0000008604.09751 .01 .

[53] Zhang JY. Metagenomic studies on cyanobacterial blooms in Lake Taihu[Dissertation]. Nanjing: Sourtheast University, 2018. [张军毅. 太湖蓝藻水华的宏基因组学研究 [学位论文]. 南京: 东南大学, 2018.]

[54] Paerl HW, Hall NS, Calandrino ES. Controlling harmful cyanobacterial blooms in a world experiencing anthropogenic and climatic-induced change. Science of the Total Environment, 2011, 409(10) : 1739-1745. DOI: 10.1016/j.scitotenv.2011. 02.001.

[55] Dokulil MT, Teubner K. Cyanobacterial dominance in lakes. Hydrobiologia, 2000, 438(1/2/3) : 1-12. DOI: 10.1023/ A: 1004155810302 .

[56] Zhang YX, Zhang YC, Zhou W et al. Inherent optical properties of typical cyanobacteria in eutrophic lakes. J Lake Sci, 2018，30(6) : 1681-1692. DOI: 10.18307/2018.0620. [张壹萱, 张玉超, 周雯等. 富营养化湖泊典型水华蓝藻的固 有光学特性. 湖泊科学, $2018,30(6): 1681-1692$.

[57] Wang XD, Liu XG, Lu SM et al. Photosynthetic activities of cyanobacterial blooms of different concentrations under aerobic conditions with aeration. China Environmental Science, 2019, 39(8) : 3412-3419. [王小冬, 刘兴国, 陆诗敏等. 不 同浓度蓝藻水华在好氧条件下的光合作用. 中国环境科学, 2019, 39(8) : 3412-3419.] 